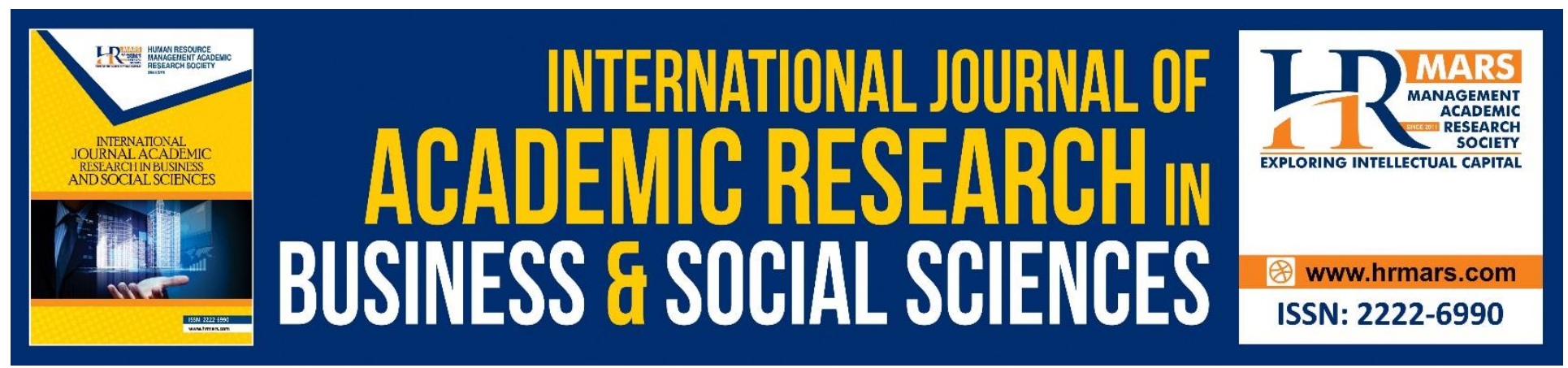

\title{
Effect of Strategic Orientation on Performance of Private Technical Training Institutions in Uasin Gishu County, Kenya
}

\author{
Naomi Chepkosgei, Caleb Akuku, Robert Onyango
}

To Link this Article: http://dx.doi.org/10.6007/IJARBSS/v9-i3/5771 DOI: $10.6007 /$ IJARBSS/v9-i3/5771

Received: 01 Feb 2019, Revised: 15 Feb 2019, Accepted: 1 March 2019

Published Online: 13 March 2019

In-Text Citation: (Chepkosgei, Akuku, \& Onyango, 2019)

To Cite this Article: Chepkosgei, N., Akuku, C., \& Onyango, R. (2019). Effect of Strategic Orientation on Performance of Private Technical Training Institutions in Uasin Gishu County, Kenya. International Journal of Academic Research in Business and Social Sciences, 9(3), 1115-1122.

Copyright: (C) 2019 The Author(s)

Published by Human Resource Management Academic Research Society (www.hrmars.com)

This article is published under the Creative Commons Attribution (CC BY 4.0) license. Anyone may reproduce, distribute, translate and create derivative works of this article (for both commercial and non-commercial purposes), subject to full attribution to the original publication and authors. The full terms of this license may be seen at: http://creativecommons.org/licences/by/4.0/legalcode

\section{Vol. 9, No. 3, 2019, Pg. 1115 - 1122}




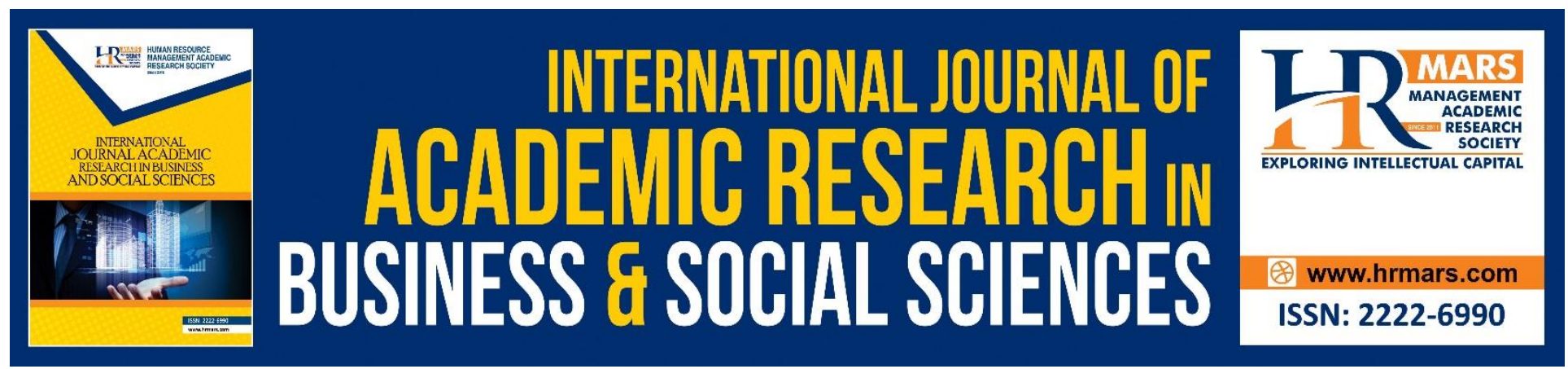

\title{
Effect of Strategic Orientation on Performance of Private Technical Training Institutions in Uasin Gishu County, Kenya
}

\author{
Naomi Chepkosgei ${ }^{1}$, Caleb Akuku², Robert Onyango ${ }^{3}$ \\ ${ }^{1}$ Jomo Kenyatta University of Agriculture and Technology \\ ${ }^{2}$ Kissi University \\ ${ }^{3}$ Masinde Muliro University of Science and Technology
}

\begin{abstract}
The unprecedented rate of dynamism of the global business environment prompts organizations to be strategically oriented in order to neutralize the forces that threaten their performance. Thus performance of TVET institutions in Kenya depends on how swiftly the sectors respond to prevailing and emerging challenges that are inherent in a developing economy such as poverty and matching training of skills with the actual demands of industry and create a deliberate link between TVET and the aspirations of the Vision 2030. In this regard the current study was designed to assess the effect of quality orientation, entrepreneurial orientation and learning orientation on performance of private TIVET institutions in Uasin Gishu County. Specific objectives was informed by configuration theory and resource based theory which has the potential to provide a conceptual guide in maximizing performance of private TIVET institutions. In a bid to effectively achieve these objectives, the study adopted a descriptive survey design based on a target population and sample size of 182 respondents drawn from across 34 private TVET institutions in Uasin Gishu County. Census technique was adopted to select the respondents. Data was collected by use of self-administered structured questionnaires. Data was analyzed by use of both inferential and descriptive statistics using SPSS version 23. From the model summary the results showed that all the two predictors (Quality orientation and Entrepreneurial orientation) jointly explained $48.8 \%$ per cent variation on performance of private TIVET institutions. The Beta value for quality orientation (.472) and entrepreneurial orientation (.322), were all positive. This implies that the management of private TIVET institutions should pay high premiums in formulating and implementing strategies in tune with environmental munificence to effectively galvanize their competitiveness and performance.
\end{abstract}

Keywords: Strategic Orientation and Performance 


\section{Background of the study}

The unprecedented rate of dynamism of the global business environment prompts organizations to be strategically oriented in order to neutralize the forces that threaten their performance. In this regard organizations strive to improve performance by developing and implementing effective business strategies that exploit opportunities in the marketplace while capitalizing on available resources and capabilities (Hilman \& Kaliappen, 2014; Masa'deh, Tarhini, Al-Dmour \& Obeidat, 2015). Strategic orientation, as a cultural attribute influences the ability of a firm to focus strategic direction and build or sustain the proper strategic fit for superior firm performance. However, apart from exercising strategic orientation, firms are also encouraged to ensure alignment of different sets of organizational capabilities in order to pursue continuous innovation for sustainable success (Masa'deh \& Shannak, 2012; Thoumrungroje \& Racela, 2013).

Strategy is multi-dimensional and situational, and encompasses the adaptation and positioning of firms internal resources, capabilities and activities, and combinations thereof, both in response to threats and in exploiting opportunities present in the business external environment (Samuel \& Mula, 2008). Orientation is described as firm's tendency to adopt particular norms, and acts or function in specific way (Cadogan, 2012). Strategic orientations therefore describe how resource allocation and coordination patterns are brought into embedded and adopted within the firm. Strategic orientation focuses on resources to achieve desired outcomes (Nduati \& Kavale, 2015 ). According to Whipp et al., (1989) strategic orientation as a cultural dimension has also been defined as a continuous and iterative process that must focus on the different effects of rational, economic, political and subjective aspects of strategic change on competitive performance (Franczak, Larry \& Michel, 2009). Strategic orientation has a positive and significant relationship with organization performance (Hakala, 2010; Abiodun \& Ibiduni, 2014). Therefore, Strategic orientation remains a cultural attribute that influences the ability of a firm to focus strategic direction and build or sustain the proper strategic fit for superior firm performance.

Hao and Song (2016) opines that strategic orientation does not automatically lead to better performance. This argument is hinged on the fact that organizational performance relies on the ability of the organization to attain its goals by using resources in an efficient and effective manner. This incriminates the essence of strategic focus on resources as a precursor of organizational performance. However whether resources are plentiful or scarce has different implications for organizations based on their strategic utilization to support organizational performance. The effect of strategic orientation on organizational performance borrows from Freemans (1984) Stakeholders theory and Penrose (1959) resource based view. Resource Based View posits that a firm's superior performance is achieved when the unique and valuable resources are controlled by the firm (Dzulkarnain, Abdullah \& Shuhymee, 2012). It can, therefore, be inferred that the strategic use of the resources owned by a firm can effectively help a firm achieve superior performance. The strategic formulation and implementation of strategies for exploiting the resources owned by a firm is pegged on what bullets a firm has in its clip. This gives credence to the adoption of stakeholder's theory in galvanizing high performance of private 
TIVET institutions. Stakeholder theory provides a vehicle for connecting business performance and strategy and that firms that diligently seek to serve the interests of a broad group of stakeholders will create more value over time (Jeffrey \& Wicks, 2013).

Globally the private sector is playing an increasing role in the provision of demand driven Technical and vocational education. However, there is a difference between developed and less developed countries in terms of their first priorities regarding TVET (Margarita, 2014 ). The first group of countries emphasize quality improvement, monitoring and evaluation of TVET, the availability of national development plans, but the second group of countries focus on the cost of enrolment and implementation of TVET (CPSC, 2010). In Asia there is a quick expansion and investment in technical and vocational education and training (TVET), and subsequently in higher education to supply skilled workers to sustain high economic growth and gradual transition to a knowledge economy (Miranda, 2014). However there is an outcry in Asia about the poor performance of (TVET), calling strategic orientation and public private partnership (Sungsup, 2014). In Cambodia's poor performance of TVET reflected in terms of Skills shortages occasioning recruitment difficulties and skills gaps among existing workers are main challenges of firms, including exporters calling for strategic orientation (Navy \& Siem, 2017).

There is unfortunately a paucity of evidence-based information about performance of TIVET particularly in Sub-Saharan Africa to assist those African policy makers involved in TIVET at any level in making informed decisions (Kingombe, 2011). Kigombe (2011) adds that Niger is the worst performer with a significant fall in the total number enrolled in TIVET despite the Government of Niger's reform of the TIVET system in 2006. In South Africa TIVET colleges are functioning in an environment rife with challenging institutional and curricular changes which compromises on their performance (Tercia, 2017). This poor performance of TIVET in South Africa incriminates ineffective and fragmented leadership and strategic management practices for this state of affairs in the performance of TIVET institutions (Badenhorst \& Radile, 2018).

In Kenya, despite the critical role played by the SMEs where private TIVET institutions is not an exception, most of the business startups are faced with many challenges where over $90 \%$ of the businesses fail at their third year (Njoroge \& Gatungu, 2013). Mullei and Bokea, as cited in Wambugu (2005) stated that in Kenya, very few enterprises have grown into large formal organizations, an adverse scenario that is apparently common among private TIVET institutions. Strategic management practices are practiced in an unsystematic and uncoordinated manner by the private universities in Kenya thus compromising on their performance (Mutegi, 2012). In order to meet ever increasing expectations and achieve sustainable competitive advantage in Kenya, and in the world, private universities must implement strategic management practices which are directly related to the concept of quality, human and technological infrastructures (Ngirwa, 2013).

In Kenya there are higher education gaps amongst Kenyans and education thirst coupled with entrepreneurial spirit of Kenyans has contributed to mushrooming of private TVET institutions (middle levels colleges) in almost every part of the country ( $\mathrm{Ng}^{\prime}$ ang'a, 2016). Private TVET institutions following strategic orientation may realize a performance advantage over 
competitors that pursue other strategies or those that are stuck in the middle (Gituku, 2015). Against this backdrop there are many of these private middle level colleges which have ultimately collapsed even before breaking even (Ng'ang'a, 2016). This calls for their adoption of strategic orientation as their blue print of achieving sustainability and high performance. Empirical studies have however found a conflicting research findings (Kellermanns et al, 2005) cited in (Ogunkoya \& Shodiya, 2013).

\section{Statement of the Problem}

Kenya can reorient itself towards sustainable development through Technical, Vocational Education and Training (TVET) (Sikasa, 2017). However the performance of TVET institutions in Kenya depend on how swiftly the sectors respond to prevailing and emerging challenges that are inherent in a developing economy such as poverty and matching training of skills with the actual demands of industry and create a deliberate link between TVET and the aspirations of the Vision 2030 (TVET, 2012). Just like any organization the performance of TVET institutions depends on their strategic orientation, which is invariably determined the nature of its strategic plans (Choy \& Mula, 2008). Strategy is multi-dimensional and situational, and encompasses the adaptation and positioning of a firms internal resources capabilities and activities which are incarnate of environment munificence, and combinations thereof, both in response to threats and in exploiting opportunities present in the firms external environment (Rothaermel, 2008). In this regard it can be hypothesized that environment munificence can moderate the effect of strategic orientation on performance of TVET institutions. Companies across sectors are struggling to find suitable candidates for job vacancies because the TVET courses offered at various training institutions often do not meet the requirements of the private sector (Samuel, 2017). Besides private middle colleges have mushroomed in the country, however many have ultimately collapsed even before breaking even ( $\mathrm{Ng}^{\prime}$ ang'a, 2016). These failures and poor performance have been ascribed to strategic disorientation (Gituku, 2015).

Empirical studies have however found a conflicting research Kellermanns et al, 2005 cited in (Ogunkoya \& Shodiya, 2013). Strategic orientation does not automatically lead to better performance (Hao \& Song, 2016). This is under pinned by the fact that the relationship between strategic orientation and firm performance is influenced by intervening factors that moderate and or mediate the relationship (Andreas \& Marcus, 2010 ; Zheng, Yang \& McLean, 2010). These altogether have invoked the need for filling the existing gaps in literature by interrogating the moderating role of environment munificence on the effect of strategic orientation on the performance of TVET institutions in Uasin Gishu County.

\section{Research objectives}

The study was guided by the following general and specific objectives

\section{General Objective}

The general objective was to assess the effect of strategic orientation on performance of private TIVET institutions in Uasin Gishu County 


\section{Specific Objectives of the Study}

The study was guided by the following specific objectives

i. To determine the effect quality orientation on performance of private TIVET institutions in Uasin Gishu county.

ii. To examine the effect of entrepreneurial orientation on performance of private TIVET institutions in Uasin Gishu county.

\section{Hypotheses of the Study}

The study was guided by the following hypothesis

$\mathbf{H O}_{1}$ : There is no statistically significant effect of quality orientation on the performance of private TIVET institutions in Uasin Gishu county.

$\mathbf{H O}_{2}$ : There is no statistically significant effect of entrepreneurial orientation on the performance of private TIVET institutions in Uasin Gishu County.

\section{Theoretical Review}

Under theoretical review we look at configuration theory and resource based theory which attempt to explain theoretically the effects of strategic orientation on business performance.

\section{Configuration Theory}

The Configuration theory was advanced by O'Cass and Ngo (2007) and States that there is need for a strategic fit between a firm's strategic focus and internal organization characteristics and which should lead to improved performance. The configuration theory appreciates that a firm's level of leverage will influence its ability to build, integrate and reconfigure internal and external capabilities so as to address the rapidly changing business environments. Configuration theory therefore refers to an organization's ability to produce new and innovative forms of competitive advantage given market positions and path dependencies (Johnson, Sholes \& Whittington, 2008). According to configuration theory, synergy is a key element in combining the capacity of individual organizations across different organizations to enhance coordination.

As business partners synergies to coordinate their businesses, they are seeking for more than just a mere exchange of resources. Rather, they are after the potential ability of the firms to enjoy value added advantages through the integration of individual firm resources so that the overall effect of sharing these resources is greater than the combination of individual organizational contribution. Eisenhardt and Martin (2000) explain the importance of configuration of the firm resources to adapt to the fast changing environment and therefore in business environments that are fast changing dynamic capability view explains the formation of firm's level of competitiveness. This is because, they are considered a transformer for converting resources into improved performance. King and Tucci (2012) found that firms can increase the probability of success in new market exploration, and the arrangement to integrate industry development during product development. The configuration of internal resources should be guided by the level of competition in the market and not only the available resources in the market. 
INTERNATIONAL JOURNAL OF ACADEMIC RESEARCH IN BUSINESS AND SOCIAL SCIENCES

Vol. 9, No. 3, March, 2019, E-ISSN: 2222-6990 @ 2019 HRMARS

Consequently, a combination of both the ESPT and the configuration theory will be appropriate nexus in explaining the role of firm's strategic orientation on firm performance.

\section{Resource Based View}

Grounded in Barney's (1991) theory on the resource based view (RBV) states that organizations that own "strategic resources" have important competitive advantages over organizations that do not. Some resources, such as cash and trucks, are not considered to be strategic resources because an organization's competitors can readily acquire them. Instead, a resource is strategic to the extent that it is valuable, rare, difficult to imitate, and non-substitutable (Hao \& Song, 2016). This theory considers that, on one hand, the firms are constantly creating new combinations of capabilities and, on the other hand the market competitors are continually improving their competences or imitating the most qualified competences from other firms (Teece, 2008). According to resource based view of a firm, researchers have defined strategic orientation as an attribute that influences the ability of a firm to focus on strategic direction of the firm and build or sustain the proper strategic fit for superior firm performance (Davidsson, Wiklund \& Brown, 2009). Since strategic orientation will vary from one organization to the next; and vary based on contextual organizational variables, strategic orientation is viewed as a multidimensional construct (Avci, Madanoglu \& Okumus, 2011). Therefore organizations use resource allocation and environmental cues to determine the right plan for the company to achieve its goals (Lau \& Ngo, 2010). Based on strategic management literature, strategic orientation increases the likelihood of share goals, making it easier to implement effective processes and improve performance.

Basically, RBV describes a firm in terms of the resources that firm integrates. Resources are insufficient for obtaining a sustained competitive advantage and a high performance as well (Teece, 2008). Being so, firms must be able to transform resources in capabilities, and consequently in a positive performance. Firms reach a superior performance, not because only they have more or better resources, but also because of their distinctive competences (those activities that a particular firm does better than any competing firms) allow to do better use of them. In the dynamic perspective, capabilities approach is a theoretical stream inside the RBV (Tajeddini \& Mueller, 2009). This approach puts emphasis on internal processes, assets and market position as restricting factors not only the capability to react but also the management capability to coordinate internal competences of the firms. While a significant body of literature exists examining the impact of strategic orientation and growth in large firms, generalizing these findings to TVET institutions is suspect. The impact of strategic orientation on TVET institutions will differ from other businesses based on resource allocation constraints and capabilities of the firm (Harrim, 2010). According to Foss and Knudsen, (2010) indicate that resource based view theory has been widely criticized and just to mention a few they say RBV has no managerial implications, The RBV implies infinite regress and The RBV's applicability is too limited.

\section{Effects of Quality Orientation on Organization Performance}

Quality orientation refers to the organizational wide proclivity on continuous improvement and coordinated teamwork and considers the customers as the ultimate value of the organization 
(Baird, Jia Hu \& Reeve, 2011). Quality is very commonly referred to as the capacity of meeting and exceeding customers' needs and expectations which add value to organization's products, to managerial processes or to the combinations of any of them. Quality philosophy is a cultural phenomenon to gain and sustain competitive advantage. Besides that, wide organizational quality orientation reflects its outcomes in the degree of organizations' innovative capability (Adams, Jeanrenaud \& Bessant, 2016). Continuous improvement endeavors can be succeeding by the commitment of functional teams that are engaged in quality management (Bulut, 2017).

These quality management orientation dimensions were derived from literature focusing on customer orientation, quality responsibility, prevention, and process orientation (Damjan, Matjaz \& Bostjan, 2014). Process orientation is the process management practice that reflects an organization's commitment to enhance the reliability and control for performance and at the same time search for better methods to improve the processes (Wu, Zhang \& Schroeder, 2011). In this regard management has a salient responsibility of stimulating and supporting the effort of employees to improve processes. In particular, organizations can enhance their performance by improving the efficiency of the processes as well as putting a strong focus on continuous improvement (Wu et al. 2011). The organization should prevent defects which is in turn a cost through quality assurance and quality management systems by use of quality management tools and methods across the production processes (Damjan, Matjaz \& Bostjan, 2014). Responsibility also plays a vital role in quality culture. Hence, for an organization, a quality culture is one in which everybody is responsible for quality improvement (Sallis, 2014). In connection with customer orientation Dean and Bowen (1994) cited in Damjan, Matjaz and Bostjan, (2014) noted that the goal of satisfying customers is fundamental to quality management and is expressed by the organization's attempt to design and deliver products and services that fulfill customer needs. Kaplan and Norton (1996) cited in Rushton, Croucher and Baker, (2014) also defined four main areas of customer concern: time, quality, cost, and performance.

Previous studies indicate relationship between quality orientation and management performance Sitimalakorn \& Hart, (2004) cited in (Gülhan \& ZaferAcar, 2015). Besides previous studies reported mixed and ambiguous results of the relationship between TQM practices and performances. Quality orientation reduces costs by improving organizational performance, promoting customer loyalty, attracting new customers. All these factors increase the productivity of an organization (Hoyer, Chandy, Dorotic, Krafft, \& Singh, 2010). Organizations embracing quality orientation would receive above average returns ascribed to understanding the market needs before their competitors. Then it may result in reducing their costs to compete with their rivals which are pursuing the same or similar strategies. By reacting quickly to customer needs and by offering new products and services they reduce the likelihood of losing customers and thereby increase customer retention. Thus, the quality of product and services increases organizational performance by acquiring a competitive advantage based on product proactivity and cost leadership (Cameron \& Quinn, 2011). Organizations which have a proclivity of quality orientation to enhance their survival. However, quality orientation as business philosophy consider not only the customer focus on quality offering but also a key drive of market share and leads to higher financial performance (Menor \& Roth, 2008). Nevertheless, literature of quality 
orientation focuses on the customer at the expense of the employees' attitudes which all in total affect the quality orientation and performance for the organization staff (Chiang, Birtch \& Kwan, 2010).

Gülhan and ZaferAcar, (2015) in their study are to demonstrate the associations between the dimensions of learning orientation and quality orientation and assessing their impact on the performance of organizations. They empirically tested and proven the relationship via extensive field research. They reached out to 85 hospitals from about 181 hospitals located in Istanbul province and collected a total of 190 responses from them as a part of this research study. After excluding 13 questionnaires with missing information, 177 responses were analyzed using correlation and regression analysis. Results reveal that learning and quality orientation positively influence the dimension of firm performance. The findings of this research support the view that implementing learning and quality orientations in the private health care organizations in Turkey will improve their overall performance. However, the study had certain limitations which give credence for further studies. The study was conducted in Turkey private hospitals which limits the generalization of its findings in the Kenyan sector and more so the private technical institutions our to differences contextual and institutional cultures.

\section{Effects Entrepreneurial Orientation on Organizational Performance}

Entrepreneurial orientation (EO) refers to the business perspective encompassed and used by an enterprise, the firms level of behavior, the management practices, the owner manager behavior and an approach that anticipates new market and product needs (Marino, K. \& Weaver, 2012). On the other hand, a commercial company is one that involves in product market advancement, accepts dangerous speculations and is major to originate "proactive" innovations and in the process outperforming competitors. Therefore, the popular dimensions that define entrepreneurial orientation include advancement, practicality (proactiveness), inventions and risk taking attributes. Latter, Lumpkin and Dess (2008) argued that two other elements that define entrepreneurial orientation are competitive aggressiveness and autonomy though Miller (1997) noted that not all dimensions were equally imperative for the success of a venture, but rather depend on the nature of the business and stage of its life cycle.

Entrepreneurs will always seek to identify an existing opportunity and capture the same before a competitor. EO determines a firms willingness to stay ahead of its competitors and to seize new opportunities by innovating in an uncertain environment. According to Renko, Carsrud and Brannback (2009) EO includes innovativeness, pro activeness, and risk taking. Innovativeness involves the use of new technology in new products/services. Therefore, innovativeness means that firms make an attempt to employ creativity and experimentation by introducing new products or services, which enhances new product performance. Further, product innovation requires firms to disconnect from existing technologies and practices, which might cause higher costs and reduce the overall firm performance. 
Entrepreneurial orientation is a firm's tendency towards searching for new market opportunities, strengthening and restoring its current market status (Balatbat, 2010). This orientation involves being highly proactive against market opportunities, tolerant to risks and sensible to innovations. In an economy, entrepreneurship means all kinds of efforts to make raw material, labor force and other production resources more valuable than they were in the beginning (Matsuno, Mentzer \& Ozsomer, 2009). Entrepreneurial orientation reflects a mentality that consists of decisions, application and continuous searching which creates new business opportunities (Micheels \& Gow, 2010). Nonetheless, in contemporary entrepreneurship studies, entrepreneurship is considered as an organizational level.

Entrepreneurial orientation is a firm's tendency to try to reach new markets, search for new market opportunities and hold on to current markets; in short, its tendency towards being able to show marketing dynamism and its ability to react to the changes in the market. Entrepreneurial orientation or tendency is an understanding that requires being highly proactive against market opportunities and market dynamism, tolerant to risks and flexible against changes (Hayton, 2005). In addition; being pacesetter for change, taking risks and making innovations are distinguishing qualifications of entrepreneurial orientated firms. Being more proactive against new opportunities and being able to behave properly to innovation strategies against the mentioned opportunities are requirements of entrepreneurial orientation. Producing better goods and services aren't the only ones in the strategic goals of entrepreneurial orientated firms; at the same time, they also aim to move beyond the expectations of their customers (Alam, Arumugam \& Nor, 2013).

Entrepreneurial orientation as a strategic orientation is concerned with the entrepreneurial aspects of a firm's strategy. It determines a firm's willingness to stay ahead of its competitors and to take advantage of new opportunities to engage in innovation in an uncertain environment Entrepreneurial orientation is defined as an organization's willingness to find and accept new opportunities and implementing change as a result(Al-Ansaari, Bederr \& Chen, 2015). It also refers to the way organizations capture specific entrepreneurial aspects of decision making styles, methods, and practices. In other words, entrepreneurial orientation relates to the methods, practices, and decision making styles that managers use to act entrepreneurially (Tutar, Nart \& Bingöl, 2015). The entrepreneurial orientation concept suggests that firms should be entrepreneurial in order to achieve superior performance. This means that organizations need to have a strategic commitment to specific, observable actions in the form of innovation, proactiveness, and risk taking, and the strong support of those actions by top management (Yang, Wang, Zhu \& Wu, 2012).

The entrepreneurial orientation concept suggests that firms should be entrepreneurial in order to achieve superior performance. This means that organizations need to have a strategic commitment to specific, observable actions in the form of innovation, proactiveness, and risk taking, and the strong support of those actions by top management (Kuratko, 2010). According to Santos and Eisenhardt (2009) engaging in product-market innovation, being the first to enter 
new markets, and understanding risky ventures are at the heart of entrepreneurship. Therefore, innovativeness, risk-taking, and proactiveness are used to represent entrepreneurial orientation in this study. Innovativeness refers to "the willingness to support creativity and experimentation in introducing new products services, and novelty, technological leadership and R\&D in developing new processes". Proactiveness refers to seeking new opportunities in the market, anticipating future demands and opportunities in the market, participating in emerging markets, shaping the environment, and introducing new products and brands before their rivals. Risktaking refers to willingness to invest in large amounts of resources in projects whose results may be unknown and where the cost of failure may be high (Arif Hartono1, 2013).

\section{Conceptual Framework}

The conceptual framework shows the relationship between the independent variable and the dependent. The independent variable for this study is strategic orientation while the dependent variable is performance. The independent variable was measured in terms of entrepreneurial orientation and quality orientation which formed the objectives of the study (Valos \& Bednall, 2010).

\section{Conceptual Framework \\ Strategic Orientation}

\begin{tabular}{|l|}
\hline Quality Orientation \\
Customer orientation \\
Process Orientation \\
\hline Entrepreneurial Orientation \\
Proactiveness \\
Risk taking \\
Innovativeness \\
\hline
\end{tabular}

Organizational Performance

\section{Independent Variable}

\section{Dependent Variable}

Figure 2.1: Conceptual Framework

\section{Research Methodology}

Research Design: The study adopted a descriptive survey research, a scientific method which involves observing (surveying) and describing the behaviour of a subject without influencing it in any way (Saunders, Lewis, \& Thornhill, 2007). It enabled large amount of data to be collected from an ideal population and in a highly economical way. Often, questionnaires are used and the data collected is standardized, easily understood and easy to compare. This method was beneficial in gaining a deeper understanding of the problems being investigated through different sources of information, as well as to be able to describe a general picture of the reliability in which the problem is involved (DeVaus, 2002). 
Population of the Study: Target population is also referred to as the universe. Target population is an aggregation of study elements and refers to all members of a real or hypothetical set of people, events, or objects to which we wish to generalize the findings (Kothari, 2009). The target population consisted of all managers and heads of departments of all the private technical institutes of vocational and entrepreneurial training institutions. The assessable population is a subset of the target population. It is the part of the target population which the researcher can actually access. The assessable population consisted of 182 key informants drawn from 34 private TIVET institutions in Uasin - Gishu County.The population that was accessed were responsible for the development, implementation and evaluation of various policies and strategies within the private TVET institutions.

Sample and Sampling Technique: A sampling frame defines the members of the population who are eligible to be included in a given sample in the sense of drawing a boundary or frame around those cases that are acceptable for inclusion in the sample (Lisa, 2008). An ideal sample should neither be excessively large nor too small (Kothari C. , 2009). Sampling technique refers to the method of selecting the sample so desired; it explains the sampling design of a given study (Dessel, 2013). Sample designs may be based on two factors; the representation principle and the element selection technique. In this study census sampling technique was adopted to arrive at the sample size which is 182 respondents. Mugenda and Mugenda, (2012) explain a census as an enumeration of all items in a population which must be consistently defined for the purpose of study.

Data Collection Instruments: Collis and Hussey, (2014) noted that the research instruments are the means by which primary data can be collected and have the advantage of ensuring that more data is obtained. The study used questionnaires as well as reviewing existing literature. The questionnaire had close-ended questions and items used five point likert scale commonly used in social sciences to measure perceptions, attitudes, values and behavior (Mugenda \& Mugenda, 2008). The items adopted a Likert Scale of: (1-Strongly disagree, 2-Disagree, 3-Undecided, 4Agree and 5-Strongly agree).

Data Processing and Analysis: The questionnaires were edited and coded to improve the quality of data. The process of editing involved going through the questionnaires to find out if the respondents were able to answer the questions and whether there are any blank responses. Tabulation involved counting the number of cases that fell into various categories. Data was analyzed using descriptive (mean, standard deviation, frequencies) and inferential statistical techniques. Under inferential statistics, multiple regressions was used to determine the effect of a set of independent variable (strategic orientation ) and moderator (Environmental munificence) on dependent variable (organization performance), coefficient of correlation using the Statistical Package for Social Sciences (SPSS) version 23.0package.

The regression model was as follows:

$\mathbf{y}=\boldsymbol{\beta} 0+\boldsymbol{\beta}_{1} X_{1}+\boldsymbol{\beta}_{2} X_{2}+\varepsilon$ Equation 1

Where $y$ was organization performance, dependent variable $X$ represents strategic orientation, $\beta$ is the standardized regression coefficient. 
$\mathbf{X}_{1}$ represents quality orientation

$\mathbf{X}_{\mathbf{2}}$ represents entrepreneurial orientation

$\mathbf{B 0}$ represents the y intercept

$\varepsilon$ represents error term

Quantitative data was extracted from the questionnaires by use of frequency tables.

\section{Data Analysis, Interpretation and Discussion}

\section{Effect of Quality Orientation on Performance of Private TIVET institutions}

The model summary presented in table 1 involves quality orientation as the only independent variable. The coefficient of determination ( $R$ square) of 0.413 indicated that the model explained only $41.3 \%$ of the variation or change in the dependent variable with the remainder of $58.7 \%$ explained by other factors other than quality orientation. Adjustment of the R square did not change the results substantially, having reduced the explanatory behavior of the predictor to $40.9 \%$. This implies that an increase of quality orientation leads to an increase in the performance of private TIVET by $40.9 \%$.

Table 1: Model Summary

\begin{tabular}{llllll} 
Model & R & R Square & $\begin{array}{l}\text { Adjusted } \\
\text { Square }\end{array}$ & $\begin{array}{c}\text { R Std. Error of the } \\
\text { Estimate }\end{array}$ & Durbin-Watson \\
\hline 1 & $.643^{\mathrm{a}}$ & .413 & .409 & .355 & 1.972 \\
\hline
\end{tabular}

a. Predictors: (Constant), Quality Orientation

b. Dependent Variable: Performance of private TIVET institutions

Second, the ANOVA output was examined to check whether the proposed model was viable. Results shown in Table 2 reveal that the F-statistic was highly significant $(F=92.961 p<0.05)$, this shows that the model was valid. Thus the null hypothesis is rejected hence it can be concluded that quality orientation significantly affects the performance of private TIVET institutions.

Table 2 ANOVA

\begin{tabular}{lllllll}
\hline \multicolumn{2}{l}{ Model } & Sum of Squares & Df & Mean Square & $F$ & Sig. \\
\hline 1 & Regression & 11.684 & 1 & 11.684 & 92.961 & $.000^{\mathrm{b}}$ \\
& & 16.591 & 132 & .126 & & \\
& Residual & 126 & & \\
Total & 28.275 & 133 & & & \\
\hline
\end{tabular}

a. Dependent Variable: Performance of private TIVET institutions 
model significantly improved the ability to predict Performance of private TIVET institutions. Thus, the model was significant

\section{Regression Coefficients of Performance of Private TIVET Institutions as Explained by Quality Orientation}

Results of the regression coefficients presented in Table 3 shows that the estimates of $\beta$ values and give an individual contribution of a predictor to the model. The $\beta$ value tells us about the relationship between performance of Private TIVET institutions with the predictor. The positive $\beta$ value indicates a positive relationship between the predictors and the outcome. The $\beta$ value for Quality orientation (.643) was positive. The positive $\beta$ values indicates the direction of relationship between predictor and outcome. From the results (Table 4.11) the model was then specified as: -

$\mathbf{y}=\boldsymbol{B}_{1} X_{1}+\varepsilon$.

Equation 2

Performance of private TIVET institutions $=.643$ quality orientation $+\varepsilon$

The coefficient of the variable indicates the amount of change one could expect in performance of private TIVET institutions given a one-unit change in the value of that variable, given that all the variables in the model are standardized basing on the standardized coefficients. Result reveal standardized regression coefficient for quality orientation $(\beta=0.643)$, implies that an increase of 1 standard deviation in quality orientation is likely to result in a 0.643 standard deviations increase in performance of private TIVET institutions. T-test was used to identify whether the predictor was making a significant contribution to the model. When the t-test associated with $\beta$ value is significant then the predictor is making a significant contribution to the model. The results show that quality orientation $(t=9.642, \mathrm{P}<.05)$

Table 4.11: Regression Coefficients ${ }^{a}$

\begin{tabular}{|c|c|c|c|c|c|c|c|}
\hline \multirow[b]{2}{*}{ Model } & \multicolumn{2}{|c|}{$\begin{array}{l}\text { Unstandardized } \\
\text { Coefficients }\end{array}$} & \multicolumn{2}{|c|}{$\begin{array}{l}\text { Standardized } \\
\text { Coefficients }\end{array}$} & \multicolumn{3}{|c|}{$\begin{array}{l}\text { Collinearity } \\
\text { Statistics }\end{array}$} \\
\hline & $B$ & Std. Error & Beta & $\mathrm{t}$ & Sig. & Tolerance & VIF \\
\hline 1 (Constant) & 1.932 & .212 & & 9.129 & $\begin{array}{l}.00 \\
0\end{array}$ & & \\
\hline $\begin{array}{l}\text { Quality } \\
\text { orientation }\end{array}$ & .494 & .051 & .643 & 9.642 & $\begin{array}{l}.00 \\
0\end{array}$ & 1.000 & 1.000 \\
\hline
\end{tabular}

a. Dependent Variable: Performance of Private TIVET institutions

\section{Effects of Entrepreneurial Orientation on Performance of Private TIVET institutions}

The model summary presented in table 4 involves entrepreneurial orientation as the only independent variable. The coefficient of determination ( $R$ square) of 0.327 indicated that the model explained only $32.7 \%$ of the variation or change in the dependent variable with the 
remainder of $67.3 \%$ explained by other factors other than entrepreneurial orientation. Adjustment of the $\mathrm{R}$ square did not change the results substantially, having reduced the explanatory behavior of the predictor to $32.2 \%$. This implies that an improvement or adoption of entrepreneurial orientation has explains $32.2 \%$. Improvement in the performance of private TIVET institutions

Table 4: Model Summary

\begin{tabular}{llllll} 
& & \multicolumn{3}{c}{ Adjusted } & R Std. Error of \\
Model & $\mathrm{R}$ & R Square & Square & the Estimate & Durbin-Watson \\
\hline 1 & $.572^{\mathrm{a}}$ & .327 & .322 & .380 & 2.007 \\
\hline
\end{tabular}

a. Predictors: (Constant), Entrepreneurial orientation

b. Dependent Variable: Performance of Private TIVET institutions

Second, the ANOVA output was examined to check whether the proposed model was viable. Results shown in Table 5 reveal that the F-statistic was highly significant $(F=64.183 p<0.05)$, this shows that the model was valid. This implies that social media significantly affects performance of Private TIVET institutions.

Table 5 ANOVA

\begin{tabular}{lllllll}
\hline Model & Sum of Squares & Df & Mean Square & $F$ & Sig. \\
\hline 1 & Regression & 9.250 & 1 & 9.250 & 64.183 & $.000^{\mathrm{b}}$ \\
& Residual & 19.025 & 132 & .144 & & \\
$\quad$ Total & 28.275 & 133 & & & & \\
\hline
\end{tabular}

a. Dependent Variable: Performance of Private TIVET institutions.

b. Predictors: (Constant), Entrepreneurial Orientation

The model significantly improved the ability to predict performance of Private TIVET institutions. Thus, the model was significant.

\section{Regression Coefficients of Performance of Private TIVET institutions as explained by Entrepreneurial Orientation}

Results of the regression coefficients presented in Table 6 shows that the estimates of $\beta$ values and give an individual contribution of a predictor to the model. The $\beta$ value tells us about the relationship between performances of private TIVET institutions with the predictor. The positive $\beta$ value indicate the positive relationship between the predictors and the outcome. The $\beta$ value for entrepreneurial orientation is (.572) was positive. The positive $\beta$ values indicate the direction of relationship between predictor and outcome. From the results (Table 4.14) the model was then specified as:-

$\mathbf{y}=\boldsymbol{B}_{1} X_{1}+\varepsilon$. Equation 3

Performance of private TIVET institutions $=.572$ Entrepreneurial orientation $+\varepsilon$ 
The coefficient of the variable indicates the amount of change one could expect in Performance of private TIVET institutions given a one-unit change in the value of that variable, given that all the variables in the model are standardized basing on the standardized coefficients. Result reveal standardized regression coefficient for entrepreneurial orientation $(\beta=0.572)$, implies that an increase of 1 standard deviation in entrepreneurial orientation is likely to result in a 0.572 standard deviation increase in performance of private TIVET institutions. T-test was used to identify whether the predictor was making a significant contribution to the model. When the $t$ test associated with $\beta$ value is significant then the predictor is making a significant contribution to the model. The results show that entrepreneurial orientation $(t=7.563, P<.05)$

Table 6: Regression Coefficients

\begin{tabular}{|c|c|c|c|c|c|c|c|}
\hline \multirow[b]{2}{*}{ Model } & \multicolumn{2}{|c|}{$\begin{array}{l}\text { Unstandardized } \\
\text { Coefficients }\end{array}$} & \multicolumn{3}{|c|}{$\begin{array}{l}\text { Standardized } \\
\text { Coefficients }\end{array}$} & \multicolumn{2}{|c|}{ Collinearity Statistics } \\
\hline & $\mathrm{B}$ & Std. Error & Beta & $\mathrm{T}$ & Sig. & Tolerance & VIF \\
\hline 1 (Constant) & 1.927 & .255 & & 7.563 & .000 & & \\
\hline EO & .501 & .063 & .572 & 8.011 & .000 & 1.000 & 1.000 \\
\hline
\end{tabular}

a. Dependent Variable: Performance of Private TIVET institutions

\section{Effect of Strategic Orientation on Performance of Private TIVET Institutions.}

From the model summary of multiple regression model, the results showed that all the three predictors (Quality orientation and Entrepreneurial orientation) jointly explained $48.8 \%$ per cent variation on performance of private TIVET institutions. This showed that considering the two study independent variables, there is a probability of $48.8 \%\left(R^{2}=0.488\right)$ in predicting performance of private TIVET institutions. This implies that when private TIVET institutions embrace strategic orientation and proactively formulate policies in support of strategic orientation thence performance of private TIVET institutions is likely to improve.

Table 7: Goodness of fit model summary

\begin{tabular}{lllllll}
\hline Model & $\mathrm{R}$ & $\mathrm{R}$ & Adjusted & $\mathrm{R}$ Std. Error of $\mathrm{R}$ & \multicolumn{2}{c}{ Square Durbin- } \\
& & Square & Square & the Estimate & Change & Watson \\
\hline 1 & $.699^{a}$ & .488 & .480 & .322 & .488 & 2.101 \\
\hline
\end{tabular}

a. Predictors: (Constant), Quality orientation, Entrepreneurial orientation

b. Dependent Variable: Performance of private TIVET institutions

Table 8 reveals that the F-value of 62.429 and a p-value of 0.00 significant at $5 \%$ level of confidence indicate that the overall regression model is significant; hence, the joint contribution of the independent variables was significant in predicting performance of private TIVET institutions is likely to improve. In this regard, we reject the null hypothesis stating that there is no significant effect of strategic orientation on performance of private TIVET institutions. Instead, 
INTERNATIONAL JOURNAL OF ACADEMIC RESEARCH IN BUSINESS AND SOCIAL SCIENCES

Vol. 9, No. 3, March, 2019, E-ISSN: 222 2-6990 (C) 2019 HRMARS

the alternative hypothesis will hold true; stating that there is a significant effect of strategic orientation on performance of private TIVET institutions.

Table8 ANOVA

\begin{tabular}{lllllll}
\hline Model & \multicolumn{2}{c}{$\begin{array}{l}\text { Sum of } \mathrm{df} \\
\text { Squares }\end{array}$} & $\begin{array}{l}\text { Mean } \\
\text { Square }\end{array}$ & $\mathrm{F}$ & Sig. \\
\hline \multirow{2}{*}{$\begin{array}{l}\text { 1(without } \\
\text { moderator ) }\end{array}$} & $\begin{array}{l}\text { Regression } \\
\text { Residual }\end{array}$ & 13.798 & 2 & 6.899 & 62.429 & $.000^{\mathrm{b}}$ \\
& Total & 28.275 & 131 & .111 & & \\
\hline
\end{tabular}

a. Dependent Variable: Performance of Private TIVET institutions

b. Predictors: (Constant), Quality orientation, Entrepreneurial orientation,

\section{Regression Coefficients of Performance of Private TIVET Institutions as Explained by Strategic Orientation}

Results of the regression coefficients presented in Table 9 show the estimates of Beta values and give an individual contribution of each predictor to the model. The Beta value tells us about the relationship between performances of private TIVET institutions with each predictor. The positive Beta values indicate the positive relationship between the predictors and the outcome. The Beta value for quality orientation (.472), entrepreneurial orientation (.322) were all positive. The positive $B$ values indicate the direction of relationship between predictors and outcome. From the results in Table 4.48 the model can then be specified as: -

$Y=.472 X_{1}+.322 X_{2}+\varepsilon$, Equation 4

T-test was then used to identify whether the predictors were making a significant contribution to the model. When the t-test associated with Beta value is significant then the predictor is making a significant contribution to the model. The results show that quality orientation ( $t$ $=6.415, \mathrm{P}<.05)$, entrepreneurial orientation $(\mathrm{t}=4.374, \mathrm{P}<.05)$. These findings indicate that all the predictors of strategic orientation jointly significantly affect the performance of private TIVET institutions.

Table 10 Regression coefficients of performance of TIVET institutions

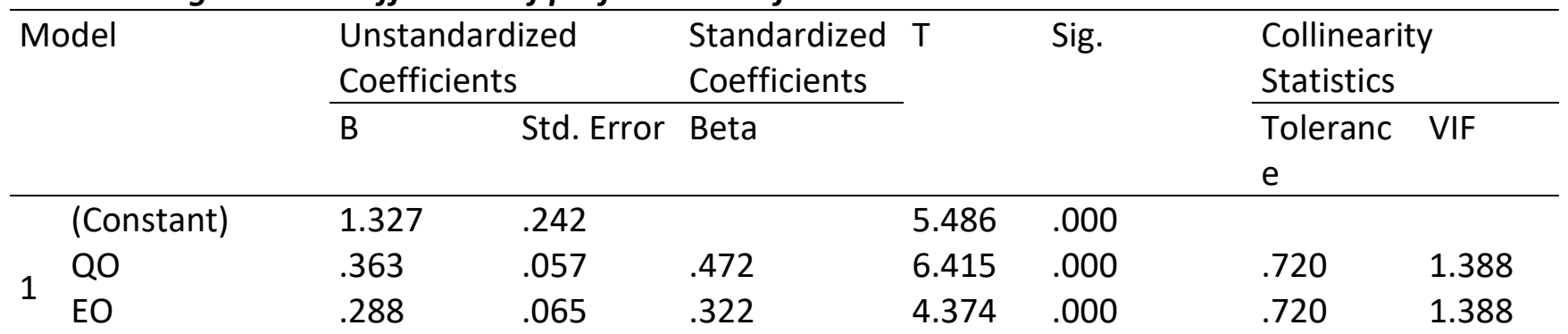

Dependent Variable: Performance of Private TIVET institutions 


\section{Discussion}

The main purpose of the study was to investigate the effect of strategic orientation on performance of TIVET institutions in Uasin Gishu County. From the results, there is no second opinion to the fact that strategic orientation affects the performance of performance of TIVET institutions in Uasin Gishu. This fact is underpinned by the findings of this study. In acknowledging the role that quality orientation plays in the strategic management of TIVET institutions. It remains the duty of the management and all the operators of the TIVET institutions to ensure that quality management is at maximum potential to secure customer satisfaction and their performance. This is underscored by the argument of Damjan, Matjaz \& Bostjan (2014) who underscored that the organization should prevent defects which are in turn a cost through quality assurance and quality management systems by use of quality management tools and methods across the operation processes. Multiple regression analysis showed that a significant relationship exists between performance of private TIVET institutions and quality orientation as indicated. Therefore, it is evident from the results that quality orientation was found to be a positive and a significant predictor of performance private TIVET institutions. Quality management is fundamental in building customer loyalty and satisfaction which engenders organizational performance. These findings are supported by Chiang, Birtch and Kwan, (2010); Cameron and Quinn, (2011) who also found a positive and significant relationship between quality orientation and organizational performance. This implies that private TIVET institutions should be strongly committed to quality operations as this can help foster their high performance.

Entrepreneurs always identify an existing opportunity to be captured ahead of its competitor. EO therefore dictates a firm's capacity to stay ahead of its competitors by innovatively seizing new opportunities in an uncertain environment. This argument is justified by the findings of this study. Standardized regression weight was found to be positive and explores that a positive relation is caused by entrepreneurial orientation in performance of private TIVET institutions as indicated. Therefore, these results are providing sufficient ground to affirm that entrepreneurial have a significant effect on the performance of private TIVET institutions in Uasin Gishu County. In this regard entrepreneurial orientation owing to its inclination towards innovation, proactiveness, competitive aggressiveness should help the private TIVET institutions to divorce or reconfigure their existing technologies and practices, which might cause higher costs and reduce their overall firm performance. Thus entrepreneurial orientation would hold supreme in engendering maximal performance of private TIVET institutions. These findings support the argument Renko, Carsrud and Brannback (2009) Tutar, Nart and Bingöl, (2015) that there is greater positive and significant link between entrepreneurial orientation and organizational performance. Therefore, private TIVET institutions must observe and measure the organization's strategies and their extent of entrepreneurial incarnation which will help them keep pace and exceed their customer's expectations besides outmaneuvering their competitors. This implies that the private TIVET institutions should strategize in embedding entrepreneurial dimensions to engender high performance. 
These findings suggest that in the light of strategic orientation as a concept, when embraced by the private TIVET institutions will contribute extensively to improving their performance. The synergistic effect of strategic orientations understudy cannot be gainsaid in achieving high performance of private TIVET institutions. This implies that the management of private TIVET institutions should pay high premiums in formulating and implementing strategies in tune with environmental munificence to effectively galvanize their competitiveness and performance.

\section{Conclusion}

It is evident that strategic orientation contributes to performance of private TIVET institutions, from the study findings. The study established existence of the dimensions of strategic orientation within the private TIVET in Uasin Gishu County. The institutions have developed unique strategic orientations in quality orientation, entrepreneurial orientation and learning orientation which have given them the ability to effectively fulfill their mandate. The study also showed that strategic orientations are significantly related to performance of the institutions.

The study provides evidence that the factors associated with quality orientation such as customer orientation, process orientation and quality responsibility. Contributes significantly to the efficacy of quality orientation in significantly enhancing performance of the private TIVET institutions. A strategic recipe which embeds these aspects of quality remains evidently instrumental. Thus the private TIVET institutions are under obligation to ensure that the processes focus on exceed quality as perceived by the customers for sustained competitive advantage and sustained performance. However, these aspects of quality should be bundled through mutually consistent policies to enhance their synergy in achieving high performance. In fine quality orientation remains the cornerstone for achieving competitive advantage and high performance of the private TIVET institutions.

Entrepreneurial orientation is imperative for the success of a venture depending on the nature of the business and stage of its life cycle. This hinges on the positive and significant effect of EO on performance of private TIVET institutions espousing from the findings of this study. It therefore remains incumbent upon private TIVET institutions to strategically orientate their entrepreneurial activities in order to affect their high performance. In view of this it remains inordinately necessary for private TIVET to analyze their entrepreneurial activities as this would proactively engender much needed innovations for competitive advantage and performance.

\section{Recommendation}

In view of the findings as well as the conclusion deduced from the study some recommendations were made. To remain sustainable and competitive in today's turbulent and dynamic environments, firms are required to acquire quality assurance and defect prevention through quality orientation strategies in organization activities. This study attempts to provide a variety of practical recommendations for guiding private TIVET institutions on how to be successful in utilizing quality orientation to attain and sustain competitive advantage and performance. The study suggests that organization should understand and develop a holistic approach of implementing overall quality assurance programs which include training and development 
strategies which focus on quality management for sustained performance. Secondly fostering a quality responsibility culture coupled with continuous improvement which remains imperative for continuous competitive advantage and performance. Correlated and complementary quality management practices should not be considered in isolation but rather should be integrated and combined to leverage on, exploit and sustain performance as actuated by competitive advantage. However this mandates organizations to assess their quality management gaps as a recipe for sustained performance.

From existing literature businesses are beset by incessant failures in performance owing to entrepreneurial incompetence. This provides a wakening call for them to embrace entrepreneurial orientation in consort with environmental munificence as a recipe for performance. This argumentation is premised on configuration and resource based view theory. There is need for tempering the dimensions of entrepreneurial orientation with some magnitude of monetary and non-monetary investments besides social networking whose absence has been incriminated for the failure of most enterprises. The processes, practices, and decision-making activities of private TIVET institutions should be incarnate of EO in order, to maintain or augment their viability and performance in the face of competition. It is, therefore, important for private TIVET institutions desirous of enhancing their performance under the moderating influence of environmental munificence to adopt virtually all the dimensions of entrepreneurial orientation.

\section{References}

Allison, P. (2015). Heteroskedasticity. Retrieved 07 11, 2018, from www3.nd.edu/ rwilliam/

Amirkhani, A. H., \& Reza, A. M. (2015). Investigating the relationshipbetween strategic orientation and firm's performance considering theintermediary role of business strategy. . Journal of Management Sciences „, 1(8), 152-157.

Andreas, K., \& Marcus, W. (2010). The Influence of Sustainability Orientation on Entrepreneurial Intentions Investigating the Role of Business Experience, . Journal of Business Venturing, , 25, 524-539.

Badenhorst, J., \& Radile, S. (2018). Poor Performance at TVET Colleges: Conceptualising a Distributed Instructional Leadership Approach as a Solution. Africa Education Review.

Bulut, C. (2017). Quality Orientation and Innovative Performance. Coimbra Business School, 3(1).

Cameron, K. S., \& Quinn, R. E. (2011). Diagnosing and changing organizational culture: Based on the competing values framework. John Wiley \& Sons.

Choy, S., \& Mula, J. M. (2008). The impact of strategic orientation dimensions on business performance: A Case Study based on an International Organisation. Retrieved 06 24, 2018, from www.researchgate.net

Collis, J., \& Hussey, R. (2014). Business research: A practical guide for undergraduate and postgraduate students. Palgrave Macmillan.

Cooper, C. R., \& Schindler, P. S. (2008). Business research methods (10 ed.). Boston: McGraw-Hill. Dessel, G. (2013). How to determine population and survey sample size? Retrieved 07 21, 2018, from https://www.checkmarket.com/blog/how-to-estimate-your-population-andsurvey-sample-size/ 
INTERNATIONAL JOURNAL OF ACADEMIC RESEARCH IN BUSINESS AND SOCIAL SCIENCES

Vol. 9, No. 3, March, 2019, E-ISSN: 2222-6990 @ 2019 HRMARS

DeVaus, D. (2002). Social Sciences Research Methodology. Allen \& Unwin.

duPlooy, N., \& Viktor, H. (2002). Assessing and improving the quality of Knowledge Discovery Data. In Data warehousing and web engineering,. IRM Press, Hershey, PA: USA, pp 198205.

Field, A. (2009). Discovering statistics using SPSS: and sex and drugs and rock ' $n$ ' roll (3rd edition). London: Sage.

Gituku, G. W. (2015). Effects of competitive strategies on performance of middle level colleges in Thika Sub County. International Academic Journal of Human Resource and Business Administration , 1(5) 83-106.

Gülhan, K., \& ZaferAcar, A. (2015). The effect o fquality orientation and learning orientation on firm performance. Research Journal of Business and Management, 2(4).

Harrim, H. (2010). Relationship between learning organization andorganizational performance (Empirical study of pharmaceutical firmsin Jordan). . Jordan Journal of Business Administration, , 6(3), 405-525.

Hoyer, W. D., Chandy, R., Dorotic, M., Krafft, M., \& Singh, S. S. (2010). Consumer cocreation in new product development. Journal of service research, 13(3), 283-296.

Jeffrey, S. H., \& Wicks, A. (2013). Stakeholder Theory, Value,and Firm Performance. Business Ethics Quarterly, 23:1 ISSN 1052-150X 97-124.

Kingombe, C. (2011). Lessons for Developing Countries from Experience with Technical and Vocational Education and Training. Paper for the International Growth Centre - Sierra Leone country programme. International Growth Centre.

Kothari, C. (2009). Research Methodology. New Delhi: New Age International publisher.

Kothari, C. R., \& Garg, G. (2014). Research methodology Methods and Techniques. New Delhi: New Age International (P) Ltd. .

Kuratko, D. F. (2010). The Corporate Entrepreneurship Process: a ResearchModel Foundations and Trends. Entrepreneurship Journal, , 3, 162-182.

Lau, C. M., \& Ngo, H. Y. (2010). The HR system, organizationalculture, and product innovation,. International business review, 13(6), 685-703.

Lisa, M. G. (2008). The SAGE Encyclopedia of Qualitative Research Methods. Retrieved 07 21, 2018, from http://methods.sagepub.com/reference/sage-encyc-qualitative-researchmethods/n414.xml

Margarita, P. ( 2014 ). TVET as an important factor in country's economic development. US National Library of Medicine , 3 (1)K3. 10.1186/2193-1801-3-S1-K3.

McDonald, J. H. (2017). Homoscedasticity and Heteroscedasticity. Retrieved 07 11, 2018, from https://stats.libretexts.org/Textbook_Maps/Biostatistics/Book\%3A_Biological_Statistics _(McDonald)/4.0/4.05\%3A_Homoscedasticity_and_Heteroscedasticity

Menor, L. J., \& Roth, A. V. ( 2008). New service development competence and performance: an empirical investigation in retail banking. Production and Operations Management, 17(3), 267-284.

Micheels, E., \& Gow, H. (2010). The Impact of Alternative Market Orientation Strategies on Firm Performance: Customer Versus Competitor Orientation, . American Agricultural Economics Association, 2010 Annual Meeting, . Colorado,: Denver. 
Mugenda, O. M., \& Mugenda, A. (2008). Research Methods: Quantitative \& Qualitative Approaches. Nairobi: African centre for Technology Studies.

Mutegi, B. (2012). Relationship among Owner/ Manager Personal Values, Business Strategies, and Enterprise Performance. Journal of Small Business Management, 35 (2), 37-61.

Nduati, P., \& Kavale, S. ( 2015 ). How does strategic orientation affect organisational competitiveness? Evidence from a large cement manufacturing firm in Kenya. Basic Research Journal of Business Management and Accounts , 4(5) 113-119.

Ngirwa, Y. (2013). Strategy Making and Environment. The Third Link, Strategic Management Journal , 4 (7),221-235.

Njoroge, C. W., \& Gatungu, J. M. (2013). "The Effect of Entrepreneurial Education and Training on Developement of Small and Medium Size Entreprises in Githunguri District -- Kenya". International Journalof Education and Research, 1 (8), 1 - 22.

Ogunkoya, O. A., \& Shodiya, O. (2013). Strategic orientation and organizational performance:a study of the African textile industry. SINGAPOREAN Journal Of business Economics, and management studies, 2(4).

Osborne, J., \& Waters, E. (2002). Four assumptions of multiple regression that researchers should always test. Practical Assessment, Research \& Evaluation. 8(2).

Rothaermel, F. (2008). competitive advantage - Scheller College of Business. Retrieved 06 24, 2018, from www.scheller.gatech.edu

Sallis, E. (2014). Total quality management in education. Routledge.

Samuel, H. (2017). Youth Employment in Kenya Literature Review. British council,Ukaid.

Saunders, M., Lewis, P., \& Thornhill, A. (2007). Research Methods for Business Students. 4th edition . Edinburgh Gate, Harlow: Financial Times Prentice Hall.

Sikasa, C. (2017). Vocational training can tackle youth unemployment. Retrieved 06 24, 2018, from from www.capitalfm.co.ke 2017/05/22/vocational-training-can-tackle-youthunemployment/

Sreevidya, U., \& Sunitha, K. (2011). Business research methods.

Sungsup, R. (2014). Innovative strategies in Technical and Vocational Education and Training for Accelerated Human Resource Development in South Asia. Retrieved 06 24, 2018, from file:///C:/Users/hp-pc/Downloads/technical_vocational_education_training__adb_2014.pdf

Tabachnick, B. G., \& Fidell, L. S. (2001). Using Multivariate Statistics (4th ed.). Needham Heights, MA: Allyn and Bacon.

Tabachnick, B., \& Fidell, L. (2007). Using multivariate statistics (5th ed). Boston: Pearson Education Inc.

Tajeddini, K., \& Mueller, S. ( 2009). Entrepreneurial characteristics inSwitzerland and the UK: a comparative study of techno entrepreneurs, . Journal of International Entrepreneurship, 7 (1), 1-25.

Teece, D. J. (2008). "Explicating dynamic capabilities: the nature and microfoundations of (sustainable) enterprise performance."Strategic Management Journal, 28(13): 13191350. 
INTERNATIONAL JOURNAL OF ACADEMIC RESEARCH IN BUSINESS AND SOCIAL SCIENCES

Vol. 9, No. 3, March, 2019, E-ISSN: 2222-6990 @) 2019 HRMARS

Valos, M., \& Bednall, D. (2010). The Alignment of Market Research with Business Strategy and CRM. Journal of Strategic Marketing, , 18, 187-199.

Williams, R. (2015). Multicollinearity . Retrieved 07 26, 2018, from www3.nd.edu 